\title{
Biochemical studies on the effect of Chitin synthesis inhibitor, (flufenoxuron) and SpliNPV on the cotton leaf worm Spodopteralittoralis Bosid (Lepidoptera:Noctuidae)
}

\author{
Reda F. A. Bakr ${ }^{1 \& 3}$; Jehane A. Hafez ${ }^{1}$ Omaima A. Khamiss ${ }^{2}$ and Ola H. Zyaan ${ }^{1}$ \\ 1- Entomology Department - Faculty of Science - Ain Shams University. \\ 2- Genetic Engineering and Biotechnology Institute - Menofeya University. \\ 3- Biology Department, Faculty of Science, King Khalid University, Abha, Saudi \\ Arabia \\ e-mail: redabakr55@gmail.com
}

\section{ABSTRACT}

In this studyflufenoxuron as insect growth regualtor and SpliNPV were used to investigate their toxicity on Spodopteralittoralis. Both $2^{\text {nd }}$ and $4^{\text {th }}$ larval instars of $S$. littoralis were exposed to the different concentrations of flufenoxuron and SpliNPV. The biochemical effect of IGR and SpliNPV on both $2^{\text {nd }}$ and $4^{\text {th }}$ larvae instar show changes in protein electrophoretic pattern in the current study reveals differences between the untreated samples and treated one, some proteins were missed or expressed at different stages which may be responsible for all the obtained deformation. The effect of these compounds on biochemical activities were revealed after studying electrophoretic protein (fractionated protein) using PAGE in order to determine their effects on the vital system of S. littoralis, which may indicate the formation of new proteins responsible for stimulating the immune system of the insect as a result of entering foreign objects inside the body of the insect.

Keywords: Spodopteralittoralis, flufenoxuron, SpliNPV, biochemical, protein.

\section{INTRODUCTION}

The cotton leafworm, Spodopteralittoralis (Boisd.) is an extremely polyphagous insect causing damage to a wide variety of crops. The cotton leafworm, Spodopteralittoralis (Boisd.) is an extremely polyphagous insect causing damage to a wide variety of crops. Moussaet al. (1960) listed some 112 plant species belonging to 44 families as food plants of Spodopteralittoralis in tropical and temperate zones of the old world. Abdel - Hafez (1978) found that from 112 plant species, 45 used as food for S. littoralis, 16 hosts for ovipositional sites and 12 for both. In Egypt, the cotton area sprayed with insecticides against leafworm varies from 10 to 65 percent of the total area; in 1991 some 69000 ha (hectares) were treated (Moawad, 1997).

In recent years, many of the conventional methods of insect control by broad spectrum synthetic chemicals have come under scrutiny because of their undesirable effects on human health and the environment (Perry, et al., 1998).Furthermore, resistance has been recorded for most conventional insecticides. As a consequence, it provides impetus to study new alternatives and more ecologically acceptable methods of insect control. The use of insect growth regulator (IGRs) offer considerable potential as agents for the suppression of many species of pest insects (Mena and Beroza 1972) and for the enhancement of the productivity of beneficial species (Murakoshiet al., 1972). Most of the compounds which have been tested show low gross toxicity to non-target organisms (Schaefer and Wilder 1972). One of the 
benefits of using benzoyl phenyl ureas (BPUs) is that they do not impact parasitoid as much as chemical pesticides (Wilkinson et al. 1978, Brown 1996 and Webb et al. 1998). Insect growth regulators have captured worldwide attention in the development of novel compounds capable of interfering with the process of growth, development and metamorphosis of the target insects (Ishaaya and Horowitz, 1997). The use of insect growth regulators (IGRs) against a variety of insect species including Spodopteralittoralis may replace some of the compounds now used for pest control which have unwanted ecological side effects or high toxicity of mammals (Abo ElGharet. al. 1994).

Chitin is an essential component in insect cuticle (Neville, 1975). Furthermore, chitin is important because it provides the cuticle with strength and a certain degree of flexibility. It protects insects against the entry of harmful substances and the exit of useful ones (notably water). The formation and decomposition of chitin are therefore carefully controlled at each stage of the life cycle (Hassall, 1990). In the absence of chitin, the cuticle becomes thin and brittle. It is also unable to support the insect or to withstand the rigors of molting compounds which interfere in any way with chitin biosynthesis. The damaged newly formed cuticle cannot withstand haemolymph pressure and muscular traction (Cohen, 1987). Benzoylphenylurea (BPU's) are insecticides acting on various insect orders by reducing chitin deposition into insect's cuticle, which in turn disrupts normal molting (Mülder\&Gijswijt, 1973; Retnakaranet al., 1985).

The moulting processes allow immature insects and other arthropods to shed the old cuticle, which is rigid and limits growth to replace it with a new one which is sufficient flexible to permit expansion and growth (Hajjar, 1985), and it was found that, the use of IGRs interfere with cuticle deposition, leading to abnormal endocuticular depositions as well as abortive moulting (Van Daalenet al., 1972; Post and Vincent, 1973).

Viruses from several taxonomic groups have been used in pest control programs. Insect viruses have been used and are in use in forestry, horticulture and agriculture; Entwhistle (1983) listed 31 lepidopterous, 6 hymenopterous and 1 coleopterous pest species for which baculoviruses control has been considered likely. The viruses that are used in pest control programmes are produced exclusively in whole insects reared in the laboratory in large scale production or purpose-built breeding facilities (Stockdal, 1984), various pesticide-NPV combinations have been evaluated for control of lepidopteran pests on cotton (Chapman and Ignoffo, 1972; Morris et al., 1974), generally with promising results. Although there have been some studies in the literature that have evaluated the impact of chemical insecticides on insect cell cultures (Mitsuhashiet al., 1970; Stipanovicet al., 1990; Yoshida et al., 1979).

In the work presented here, we select flufenoxuron; as chitin synthesis inhibitors and SpliNPV which is considered as one of the most famous occluded virus as belonging to Baculovirus group since its discovery in 1956. The mix of each IGR was also used with the virus to evaluate their biochemical effect on the $2^{\text {nd }}$ and $4^{\text {th }}$ instar larvae of Spodopteralittoralis.

\section{MATERIALS AND METHODS}

\section{1- Insect used}

Insect used in the present study was the Egyptian cotton leaf worm Spodopteralittoralis (Boisd.) (Lepidoptera: Noctuidae). It was obtained from the Plant protection, Research institute, Agriculture, Research center (Giza), and was reared in 
the laboratory under constant laboratory conditions of $27 \pm 2^{\circ} \mathrm{C}$ and $70 \pm 5 \% \mathrm{RH}$ to be used in our investigations.

\section{2- Chemicals used}

Flufenoxuron belongs to insect growth regulators (IGRs) group. It was delivered from the Plant protection, Research institute, Agriculture, Research center (Giza).

The virus used in this study was delivered from EntomovirologyCenter in the Faculty of Agriculture, CairoUniversity (Giza). Virus (nucleopolyhedrovirus) was naturally collected from recently dead larvae of Spodopteralittoralis (Boisd.). Multiplication of virus was applied by infecting $4^{\text {th }}$ instar larvae through the surface contamination of the larval diet. The infected larvae were incubated at $25^{\circ} \mathrm{C}$ for 7 days before collecting cadavers. The dead larvae were stored at $-20^{\circ} \mathrm{C}$ to obtain the virus from them. To obtain and purify virus particles (virions), polyhedra were dissolved in an alkaline solution of sodium thioglycolate buffer $0.25 \mathrm{Mol}$. 10.5 PH for 1.5-3 min. according to the concentration of polyhedra in the suspension. The dissolution of polyhedra was indicated by the clear aspect of the suspension which means the liberation of virus particles. This suspension was centrifuged at 5000 r.p.m for 5 minutes and the pellet was discarded. The supernatant which contained virion was placed on sucrose solution with a concentration graded from 20 to $60 \%$ and centrifuged at $18000 \mathrm{rpm}$ at $8^{\circ} \mathrm{C}$ for $45 \mathrm{~min}$. using a rotor. The virions were sedimented as net bands on the correspondent sucrose concentrations graded from $30 \%$ to $45 \%$ approximately. The virion bands were delicately aspired with the help of a peristaltic pump and transferred to a new centrifuge tube with about $15 \mathrm{ml}$ distilled water and then centrifuged at 20000 r.p.m at $8^{\circ} \mathrm{C}$ for $45 \mathrm{~min}$. The pellet should contain highly purified virions.

\section{3- Samples preparation:}

Untreated and treated larvae by flufenoxuron and virus from different stages were killed by freezing and stored at $-20^{\circ} \mathrm{C}$ until used. Larva of each group was homogenized in a small cold mortar containing $0.1 \mathrm{ml}$ of distilled water. The contents were transferred to a new Eppendorf tube, and centrifuged at 10,000 r.p.m. for $10 \mathrm{~min}$ at room temp. The supernatant was transferred to a new Eppendorf tube and kept frozen at $-20^{\circ} \mathrm{C}$ till further application. Protein was separated by PAGE according to the method of Laemmli (1970).

\section{RESULTS}

\section{Separation of protein bands by electrophoresis}

SDS-PAGE of protein pattern for both control and $3^{\text {rd }}$ instar of S. littoralis larvae treated as $2^{\text {nd }}$ instar with three different conc. of flufenoxuron alone or combined with SpliNPV were separated into 12 and 11 different bands, respectively.

Data demonstrated in figure (1) showed that, the total number of bands in control sample, and treated samples by $0.5 \times 10^{-2}, 0.5 \times 10^{-5} \& \quad 0.5 \times 10^{-9}$ ppmflufenoxuron were $3,5,8 \& 6$, respectively. The molecular weight of bands in all samples ranged from 14 to $69 \mathrm{~K} \mathrm{Da}$. Two common bands $3 \& 5$ were appeared between the control sample (C) and the other treated samples by three different conc. of flufenoxuron.

The data given in figure (2) screened that, the total number of bands in control samples (C), virus $3.5 \times 10^{4} \mathrm{PIB}(\mathrm{V})$ and three treated samples by virus flufenoxuron combination $\left(0.5 \times 10^{-2} / 3.5 \times 10^{4}, \quad 0.5 \times 10^{-5} / 3.5 \times 10^{4} \& \quad 0.5 \times 10^{-9} / 3.5 \times 10^{4} \mathrm{ppm} / \mathrm{PIB}\right)$ were $3,6,5,6$ and 6 respectively. 
The molecular weight of bands in all samples ranged from 16.97 to $68.7 \mathrm{~K} \mathrm{Da}$. Two common bands were appeared between the control sample and the other four treated samples by virus and virus flufenoxuron combination.

SDS-PAGE of protein pattern for both control and $4^{\text {th }}$ larval instar of S. littoralis from treated $2^{\text {nd }}$ instar with three different conc. of flufenoxuron alone and flufenoxuron combined with SpliNPV were separated into 14 and 16 different bands, respectively. From figure (2) it is obvious that, the total number of bands in control (C), $0.5 \times 10^{-2}(1), 0.5 \times 10^{-5}$ (2) \& $0.5 \times 10^{-9}$ (3) ppmflufenoxuron were $8,6,4$ and 5 bands, respectively. They were ranged from 13.7 to $67.9 \mathrm{~K} \mathrm{Da}$. in molecular weight value.

The data presented in figure (2) showed that the total number of bands in control sample (C), virus $3.5 \times 10^{4} \mathrm{PIB}(\mathrm{V})$ and three treated samples by virus flufenoxuron combination $\left(0.5 \times 10^{-2} / 3.5 \times 10^{4}, \quad 0.5 \times 10^{-5} / 3.5 \times 10^{4} \& \quad 0.5 \times 10^{-9} / 3.5 \times 10^{4} \mathrm{ppm} / \mathrm{PIB}\right)$ were $8,7,5,5$ and 6 respectively.

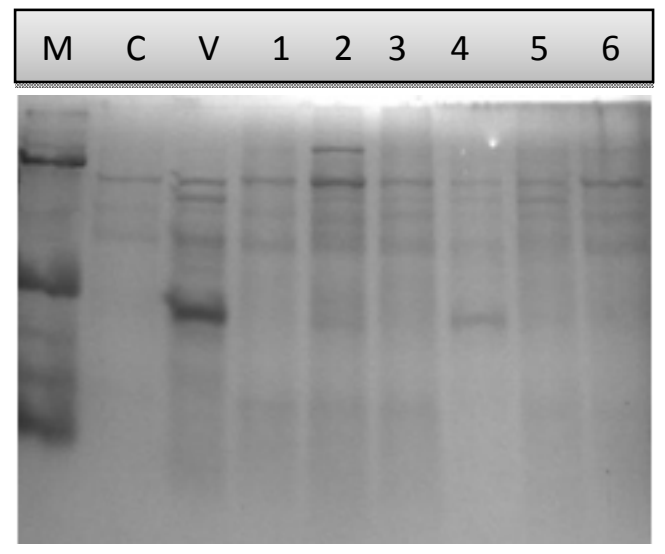

Fig. 1

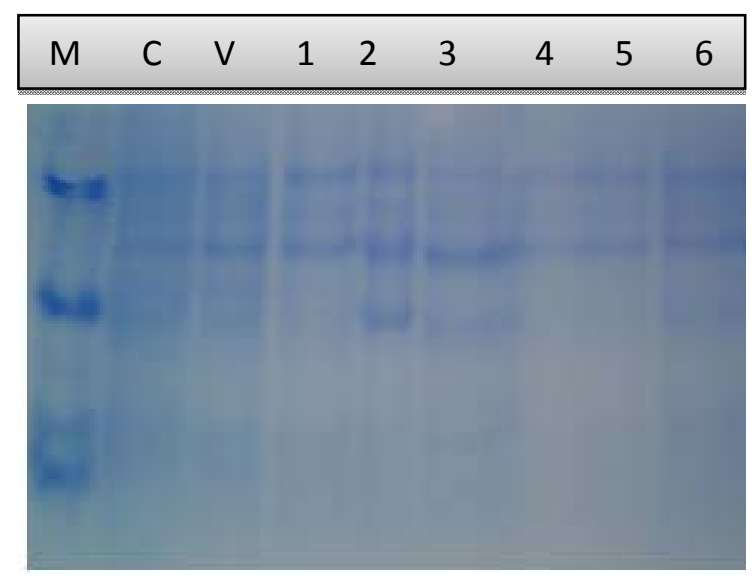

Fig. 2

SDS-PAGE of protein pattern for both control and $5^{\text {th }}$ larval instar of S. littoralis from treated $2^{\text {nd }}$ instar with three different conc. of flufenoxuron alone and flufenoxuron combined with SpliNPV were separated into 16 and 19 different bands, respectively.

The characteristic pattern of protein bands were illustrated in figure (3). Generally it was obvious that no common bands between the control sample (C) and the other three treated samples by flufenoxuron.

SDS-PAGE of protein pattern for both control and $6^{\text {th }}$ larvae instar of $S$. littoralis treated at $2^{\text {nd }}$ instar with three different conc. of flufenoxuron and flufenoxuron combined with SpliNPV were separated into 17 and 16 different bands, respectively.

The characteristic patterns of protein were illustrated in figure (4) the band No. $1,2 \& 5$ were common bands between the control sample and other treated samples by flufenoxuron.

Data recorded in figure (4) represent fractionated protein produced from treated S. littoralis larvae by virus \& virus flufenoxuron combination. The result showed that, bands No. 6, 8 \& 10 with RF $0.21,0.30$ \& 0.39 and MW 67, 61.6 \& $56.4 \mathrm{~K} \mathrm{Da}$. were characteristic bands between the control sample and the other four treated samples by virus and virus flufenoxuron combination. Band No. 6 appear in sample (V) treated by virus alone with $\%$ amount twice than in control sample. 


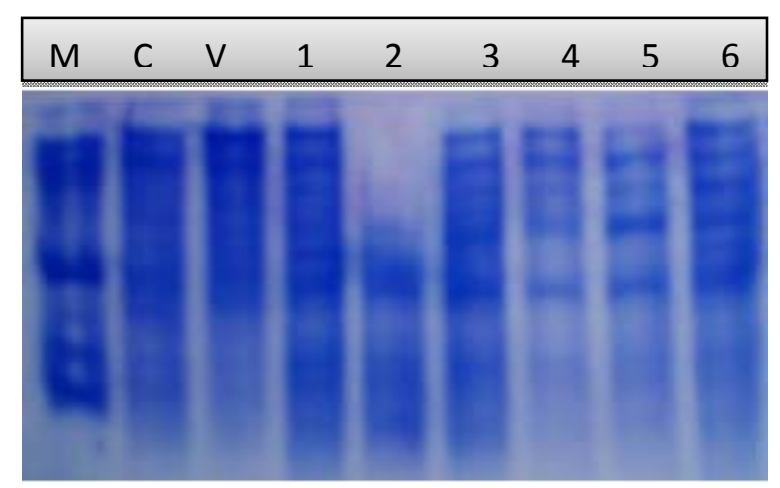

Fig. 3

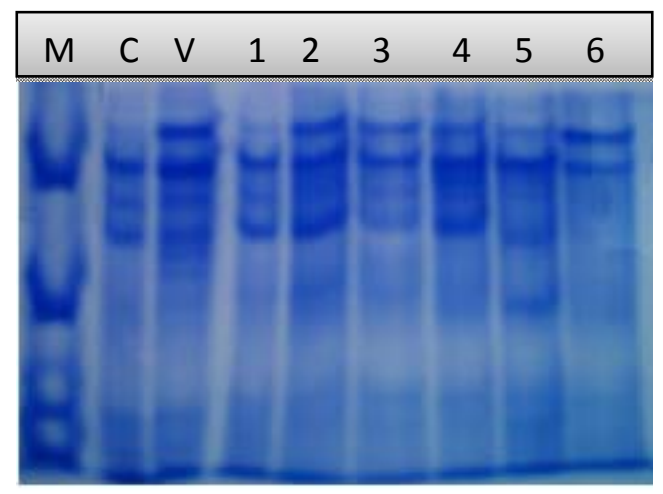

Fig. 4

SDS-PAGE of protein pattern for both control and $5^{\text {th }}$ larval instar of $S$. littoralis from treated $4^{\text {th }}$ instar with three different conc. of flufenoxuron and flufenoxuron combined with SpliNPV were separated into 16 and 17 different bands, respectively.

Data illustrated in figure (5) represent fractionated protein produced from treated S. littoralis larvae by virus \& virus flufenoxuron combination. The result showed that, bands No. 16 \& 17 with RF $0.77 \& 0.84$ and MW 13.2 \& $8.7 \mathrm{~K}$ Da. were characteristic bands between the control sample and the other four treated samples by virus and virus flufenoxuron.

combination. But band No. 17 appear in the four treated samples treated by virus $\&$ virus flufenoxuron combination by amount twice than in control sample.

Data shown in figure (6) revealed that, bands No. 1, 2, 3 \& 12 were common bands between the control sample and the other three treated samples by flufenoxuron.

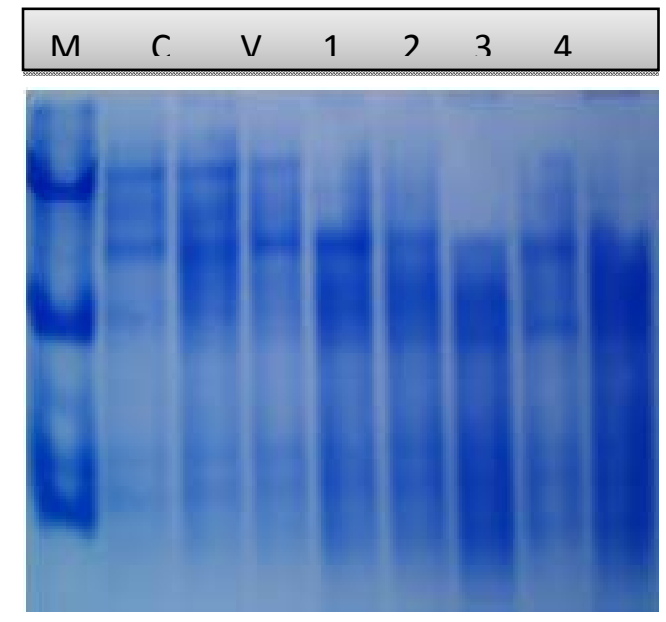

Fig. 5

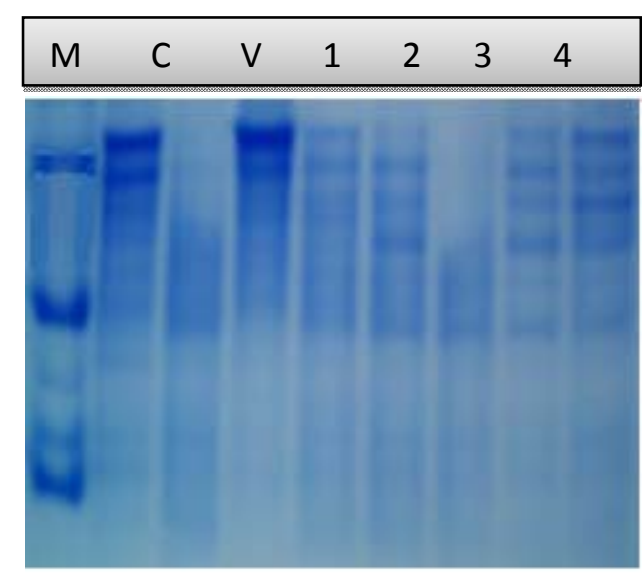

Fig. 6

SDS- Polyacrylamide gel of protein patterns of a control and $3^{\text {rd }}$ larval instar resulted from treated $2^{\text {nd }}$ instar with SpliNPV virus and insect growth regulator Flufenoxuron fig (1), SDS- Polyacrylamide gel of protein patterns of a control and 4th larval instar resulted from treated 2nd instar larvae with SpliNPV virus and insect growth regulator Flufenoxuron fig (2). Where: $\mathrm{M}=$ Marker (K Da.), $\mathrm{C}=$ Sample of control, $\mathrm{V}=$ Sample treated by virus, $1=$ Sample treated by $0.5 \times 10^{-2} \mathrm{ppm}$ flufenoxuron, $2=$ Sample treated by $0.5 \times 10^{-5} \mathrm{ppm}$ flufenoxuron, $3=$ Sample treated by $0.5 \times 10^{-9} \mathrm{ppm}$ flufenoxuron, $4=$ Sample treated by $0.5 \times 10^{-2} \mathrm{ppm}$ flufenoxuron combined with $3.5 \times 10^{4} \mathrm{PIB}$ virus, $5=$ Sample treated by $0.5 \times 10^{-5} \mathrm{ppm}$ flufenoxuron combined with $3.5 \times 10^{4}$ PIB virus, $6=$ Sample treated by $0.5 \times 10^{-9} \mathrm{ppm}$ flufenoxuron combined with $3.5 \times 10^{4} \mathrm{PIB}$ virus. 
SDS- Polyacrylamide gel of protein patterns of a control and 5th larval instar resulted from treated 2nd instar with SpliNPV virus and insect growth regulator Flufenoxuron fig (3) and SDS- Polyacrylamide gel of protein patterns of a control and 6th larval instar resulted from treated 2nd instar with SpliNPV virus and insect growth regulator Flufenoxuron fig (4). Where: $\mathrm{M}=$ Marker (K Da.), $\mathrm{C}=$ Sample of control, $\mathrm{V}=$ Sample treated by virus, $1=$ Sample treated by $0.5 \times 10-2$ ppm flufenoxuron, 2 = Sample treated by $0.5 \times 10-5$ ppm flufenoxuron, 3 $=$ Sample treated by $0.5 \times 10-9 \mathrm{ppm}$ flufenoxuron, $4=$ Sample treated by $0.5 \times 10-2 \mathrm{ppm}$ flufenoxuron combined with $3.5 \times 104$ PIB virus, $5=$ Sample treated by $0.5 \times 10-5 \mathrm{ppm}$ flufenoxuron combined with $3.5 \mathrm{X} 104$ PIB virus, $6=$ Sample treated by $0.5 \mathrm{X} 10-9 \mathrm{ppm}$ flufenoxuron combined with 3.5X104 PIB virus.

SDS- Polyacrylamide gel of protein patterns of a control and 5th larval instar resulted from treated 4th instar with SpliNPV virus and insect growth regulator Flufenoxuron fig (5), and SDS- Polyacrylamide gel of protein patterns of as control and 6th larval instar resulted from treated 4th instar with SpliNPV virus and insect growth regulator Flufenoxuron fig (6). Where: $\mathrm{M}=$ Marker (K Da.), $\mathrm{C}=$ Sample of control, $\mathrm{V}=$ Sample treated by virus, $1=$ Sample treated by $0.5 \mathrm{X} 10-2 \mathrm{ppm}$ flufenoxuron, 2 = Sample treated by $0.5 \mathrm{X} 10-5 \mathrm{ppm}$ flufenoxuron, 3 $=$ Sample treated by $0.5 \times 10-9 \mathrm{ppm}$ flufenoxuron, $4=$ Sample treated by $0.5 \times 10-2 \mathrm{ppm}$ flufenoxuron combined with $3.5 \times 104$ PIB virus, $5=$ Sample treated by $0.5 \times 10-5 \mathrm{ppm}$ flufenoxuron combined with $3.5 \times 104$ PIB virus, $6=$ Sample treated by $0.5 \times 10-9 \mathrm{ppm}$ flufenoxuron combined with 3.5X104 PIB virus.

\section{DISCUSSION}

It is worthy to mention that each protein is considered as reflect to the activity of specific gene through the production of the enzyme which act as catalyst to produce the demanded protein, this type of produced protein is responsible for a specific biological character.

The present study was carried out to clarify some biochemical effect of three concentration-levels of insect growth regulators and combination between flufenoxuron (which was more effective against $S$. littoralis than pyriproxyfen) and SpliNPV on the $S$. littoralis larvae. The data of biochemical test discussed as follow:

In the present work the general proteins of the whole body tissue of $3^{\text {rd }}, 4^{\text {th }}, 5^{\text {th }} \&$ $6^{\text {th }}$ instar of $S$. littoralis larvae treated by flufenoxuron at $2^{\text {nd }}$ instar were separated into $12,14,16 \& 17$ bands respectively. When the same instar treated by flufenoxuron combined with SpliNPV the protein bands were $11,16,19 \& 16$ bands at $3^{\text {rd }}, 4^{\text {th }}, 5^{\text {th }} \&$ $6^{\text {th }}$ instar respectively.

The $5^{\text {th }} \& 6^{\text {th }}$ instar of $S$. littoralis larvae treated by flufenoxuron at $4^{\text {th }}$ instar whole body protein were separated into $16 \& 14$ bands respectively.

In case of $5^{\text {th }} \& 6^{\text {th }}$ instar of $S$. littoralis larvae treated by flufenoxuron combined with SpliNPV, $17 \& 15$ bands respectively, were separated. Among those bands some were common between control and all treated samples while others were characteristic to certain concentration of treatment.

In comparing the bands appeared after treatment of $2^{\text {nd }}$ instar with control, it was found that, 2 bands (No. $3 \& 5$ ) share between control and larvae treated by flufenoxuron or combined with virus, the two common bands appear about two times as percentage amount in the control sample than in the treated samples. The similar results obtained by Hamouda (2002) who studied the treatment of the third instar larvae of Spodopteralittoralis by admiral alone or SNPV alone or a mixture of them caused some changes in the protein content in the treated larvae, and also, said that the decrease in the concentration of the protein in the treated larvae may reflect the inhibition of DNA synthesis and the decrease in the activity of various enzymes is related to insect growth regulators mechanism. El-Bermawy and Abulyazid 1998 
stated that, the lower concentration of protein may be resulted from DNA damaged causing shut off of some essential gene responsible for production of this protein after treatment.

The $4^{\text {th }}$ instar samples resulted from treated $2^{\text {nd }}$ instar larvae by flufenoxuron, two common bands share between them and control sample. In comparing the \% amount in the common bands between the control sample (C) and the other treated samples, it was obvious that band No. 1 in treated samples had \% amount about two times of the control sample (C), $6^{\text {th }}$ instar resulted from $4^{\text {th }}$ instar treated larvae by flufenoxuron combined with virus had a common band No. 14 with \% amount in treated samples about twice than in control, which reveal that, the higher concentration of protein may has an antagonistic effect on the population.

In general new protein bands were appeared in treated samples by the used IGRs, which may be attributed to the formation of immune protein as a result of the presence of foreign molecules (IGRs) in the larval bodies (Dunn, 1986 \&Dimarcqet al., 1990).

From these investigations, six protein bands which present in control sample were disappeared from samples of the $4^{\text {th }}$ larval instar resulted from treated as $2^{\text {nd }}$ instar by flufenoxuron. Also five bands were disappeared in samples treated by flufenoxuron combined with virus. These findings are in agreement withBakret al. (2005) who studied the effect of pyriproxyfen on fractionation protein pattern of Spodopteralittoralisand found that new and specific protein were observed in all treated samples by chlorfluazuron and pyriproxyfen, which may be responsible for all the obtained deformation. Amer and Ghoneim, (1996) who studied the effect of pyriproxyfen (IGRs) on fractionation protein pattern of Shistocercagregaria, they found that six protein bands of control were disappeared in treated samples. While Hussein et al.(1993) studied the biochemical effects of pyriproxyfen on the pink bollworm larvae, they found that, treatment with juvenoide resulted in a considerable reduction in the protein bands which reflect inactivation of the genes responsible for production of mRNA synthesize these proteins.

The protein difference may act as taxonomic tool to identify the similarity index and genetic differences between control and other treated samples as concluded by Reddy et al. (1993); Krishnayya and Rao (1995).

The increase in the concentration of protein due to virus treatment of Spodopteralittoralislarvae may explain in terms of virus replications as follows: the first and most dramatic changes caused by the NPV are the turning off the host cell protein synthesis early in the infection cycle of the virus. The second is the temporal control of viral protein synthesis evident in the appearance and disappearance of specific viral protein during this period. Both transcriptional modifications of two virus proteins were also detected during this period. Also, a highly glycosylated intracellular protein is deglycosylated giving rise to another protein. The late stage is characterized by maturations of the virus (Ignoffoet al., 1971).

In this study, the protein pattern monitors number of bands as a difference between the control and the treated samples. This difference is translated as genetic distance, which recorded a great value ranged from 0.35 to 0.85 between the control sample and the samples treated by flufenoxuron as $2^{\text {nd }}$ instar, and reach value 1 between the control sample and the samples $4^{\text {th }}$ instar treated by flufenoxuron combined with virus as $2^{\text {nd }}$ instar This great genetic distance may refers to a new taxonomic position for the treated samples apart genetically from control.

El-Bermawy (2005) treated $2^{\text {nd }}$ larval instar of $S$. littoraliswith different concentrations of cascade (flufenoxuron) and match and found that new and specific 
proteins were obtained in all examined tissue and they were probably responsible for all the obtained deformation. The untreated larval tissue recorded 9 types of protein while the cascade treated tissue had 10 types of protein meanwhile the match treated tissue had 9 types of protein. Different characteristic types of protein were recorded for each treatment.

\section{REFERENCES}

Abdel-Hafez, M. M. (1978): Some biological studies on cotton leafwormSpodopteralittoralis. Ph.D. Thesis, Fac. Agric., Cairo Univ., Cairo, Egypt.

Abo El-Ghar, G. E. S.;Khalil, M. S. and Eid, T. M.(1994): Effects of plant extracts on development and fecundity of Agrotisipslion(Hufn.)(Lepidoptera: Noctuidae). Bull. Ent. Soc. Egypt, Econ. Ser., 21:171-190.

Amer, M. S. and Ghoneim, K. S. (1996): The haemolymph protein characterization after the treatment of late last instar nymphs of the desert locust Shistocercagregaria (Forsk.) with the juvenoid S-31183. Al-Azhar Bull. Sci., 7(1): 861-870.

Bakr, R. F.; Guneidy, N. A.; El-Barmawy, S. M.; Emara, S. A. and Hassan, H. W. (2005): Toxicological and biological activites of three IGRs against fourth larval instars of the cotton leaf worm, Spodopteralittoralis (Boisd). J. Egypt. Acad. Soc. Environ. Develop; 6 (4): 103-132.

Brown, J. J. (1996): The compatibility of tebufenozide with a laboratory Lepidpteran host / Hymenoptera parasitoid population. Biol. Control, 6: 96-104.

Chapman, A. J. and Ignoffo, C. M. (1972): Influence of rate and spray volume of a nucleo-polyhedrosis virus on control of Heliothis in cotton. J. Invertebr. Pathol., 20: 183-186.

Cohen, E. (1987): Chitin biochemistry: synthesis and inhibition. Ann. Rev. Entomol., 32: $71-93$

Dimarcq, J. L. ; Zachary, D. ; Hoffmann, J. A. ; Hoffmann, D. and Reichart, J. M. (1990): Insect immunity: Experession of the two major inducible antibacterial peptides, defensin and diptericin in Phormiaterranovae. EMBO J; 9: 2507-2515.

Dunn, P. E. (1986): Biochemical aspects of insect immunity. Annu. Rev. Entomol; 31:321-329.

El- Bermawy, S. M. (2005): Screening of biological parameters, protein and 6phosphogluconate dehydrogenase as a reflex to the treatement of $2^{\text {nd }}$ larval instar of Spodopteralittoralis (Boisd.) with cascade and match. J. Egypt. Acad. Soc. Environ. Develop., 6 (4): 1-22.

El-Bermawy, S. M. and Abulyazid, I. (1998): Genomic DNA polymorphism and biochemical assay in the pupal stage of Medfly CeratitisCapitata (Wied). Proceeding of the International Congress on Molecular Genetics, Vol. 1, 165180.

Entwhistle, P. F. (1983): Viruses for insect pest control.Sp n 26:59-62.

Hajjar, N. P. (1985): Chitin synthesis inhibitors as insecticides. Jon Wiely\& Sons Ltd. Pp: 275-310.

Hamouda, L. S. (2002): Toxicological and biochemical studies on the effect of admiral (IGR) and nuclearpolyhedrosis virus (SNPV) on Spodopteralittoralis(Boisd.) larvae. J. Egypt. Acad. Soc. Envron. Develop. Vol. 2(1):15-29. 
Hassall, K. A. (1990): The biochemistry and uses of pesticides. MacMillan Press LTD, $2^{\text {nd }}$ edition.

Hussein, N. M.; Hewady, M. A.; Taher, S. H. and Abdel-Hafez, A. (1993): Biological and biochemical effects of pyriproxyfenjuvenoid on the pink bollworm larvae Pectinophoragossypiella (Saund). Al-Azhar J. of Agric. Res., 17: 221-236.

Ignoffo, C. M.; Shapiro, M. and Hink, W. F. (1971): Replication and serial passage of infectious Heliothisnuclear polyhedrosis virus in an established line of Heliothesiszea cells. J. Invertebr. Pathol., 18:131.

Ishaaya, I. and Horowitz, A. R. (1997): Insecticides with novel modes of actions: A overview. Pp: 1-39 In: Ishaaya, I. and Degheele, D. [Eds.], Insecticides with novel modes of actions: Mechanism and Application. Spriger, Berlin.

Krishnayya, P. V. and Rao, P. J. (1995): Plumbagain effect on Helicoverpaarmigera (Lepidoptera: Noctuidae) finalinstarhaemolymph protein, alpha amino acid and fat body protein content. Indian J. of Exper.Biol; 33(3): 217-221.

Laemmli, U. K. (1970): Most commonly used discontinuous buffer system for SDS electrophoresis. Nature 227:680.

Mena, J. J. and Beroza, M. (1972): Insect juvenile hormones: chemistry and action. Academic Press. New York.

Mitsuhashi, J.; Grace, T. D. C. and Waterhouse, D. F. (1970): Effects of insecticides on cultures of insect cells. Entomol. Exp. Appl., 13:327-341.

Moawad, G. M. (1997): Cotton Pest and Their Control in the Near East. United Nations. Egypt. Pp. 9-21. in FAO (ed.)

Morris, O. N.; Armstrong, J. A.; Howse, G. W. and Cunningham, J. C. (1974): A 2year study of virus chemical insecticide combination in the integrated control of the spruce budworm, Choristoneurafumiferana (Tortricidae: Lepidoptera). Can. Entomol., 106:813-824.

Moussa, M. A.; Zaher, M. A. and Kotby, F. (1960): Abundance of cotton leafworm, Prodenialitura(F.) in relation to host plant. I. Host plant and their effect on biology (Lepidoptera; Agrotidae- zenobiinae). Bull. Soc. Ent. Egypt, 44:241-51.

Mülder, R. and Gijswijt, M. J. (1973): The laboratory evaluation of two promising new insecticides which interfere with cuticle deposition. Pestic. Sci., 10:737745.

Murakoshi, S.; Change, C. F. and Tamura, S. (1972): Increase in silk production by the silk silkworm, Bombyxmori due to oral administration of a juvenile hormone analoug. Agric. Biol. Chem., 36: 695-696.

Neville, N. C. (1975): Biology of orthopod cuticle. Speringer-Verlag, New York (Cited by; Hajjar. (1985).

Perry, A. S.; Yamamoto, I.; Ishaaya, I. and Perry. (1998): Insect in Agriculture and

Enviroment: retrospects and prospects. Springer, Berlin.

Post, L. C. and Vincent, W. R. (1973): A new insecticide inhibits chitin synthesis. Naturwissenschafte, 60:431-432.

Reddy, K. D.; Bhagawa, C. N. and Sukumar, K. (1993): Depletion of amino acids and protein in the nymphalhaemolymph of the red cotton bug, Dysdercuskoenigii(Hemiptera: Phytocoridae) treated with Annonasquamosa extract. Phytophaga; 5(1): 45-50.

Retnakaran, A.; Granett, J. and Ennis, T. (1985): Insect growth regulators. In: Kerut, G. A. and Gilbert, L. I. [Eds.], Comprehensive Insect Physiology, Biochemistry and Pharmacology. Vol. (12): 529-601. Pergamon, Oxford. 
Schaefer, C. H. and Wilder, W. H. (1972): Insect development inhibitors: a practical evaluation as mosquito control agents. J. Econ. Entomol., 65: 1066-1071

Stipanovic, R. D.; Elissalde, M. H.; Altman, D. W. and Norman, J. O. (1990): Cell culture bioassay to evaluate allelchemical toxicity to Heliothisverescens (Lepidoptera: Noctuidae). J. Econ. Entomol., 83:737-741.

Stockdal, M. (1984): Microbial insecticides. In comprehensive biotechnology.Pergamon. Oxford, (2):543.

Van Daalen, J. J.; Maetz, J.; Mulder, R. and Wellinga, K. (1972): A selective insecticide with a noval mode of action. Naturwissenschaften, 59: 313-317.

Webb, R. E.; Peiffer, R.; Fuester, R. W.; Thorpe, K. W.; L. and Calabrese, J. M. McLaughlin (1998): An evaluation of the residual activity of traditional, safe and biological insecticides against the gypsy moth. J. Arbor., 24: 286-293.

Wilkinson, J. D.; Biever, K. D.; Ignoffo, C. M.; Pons, W. J.; Morrison, R. K. and Seay, R. S. (1978): Evaluation of diflubenzuron formulation on selected insect parasitoids and predators. J. Ga. Entomol. Soc., 13: 227-236.

Yoshida, M.; Onaka, M.; Fujita, T. and Nakajima, M. (1979): Inhibitory effects of pesticides on growth and respiration of cultured cells. Pesticide Biochem. Physiol., 10: 313-321.

\section{ARABIC SUMMERY}

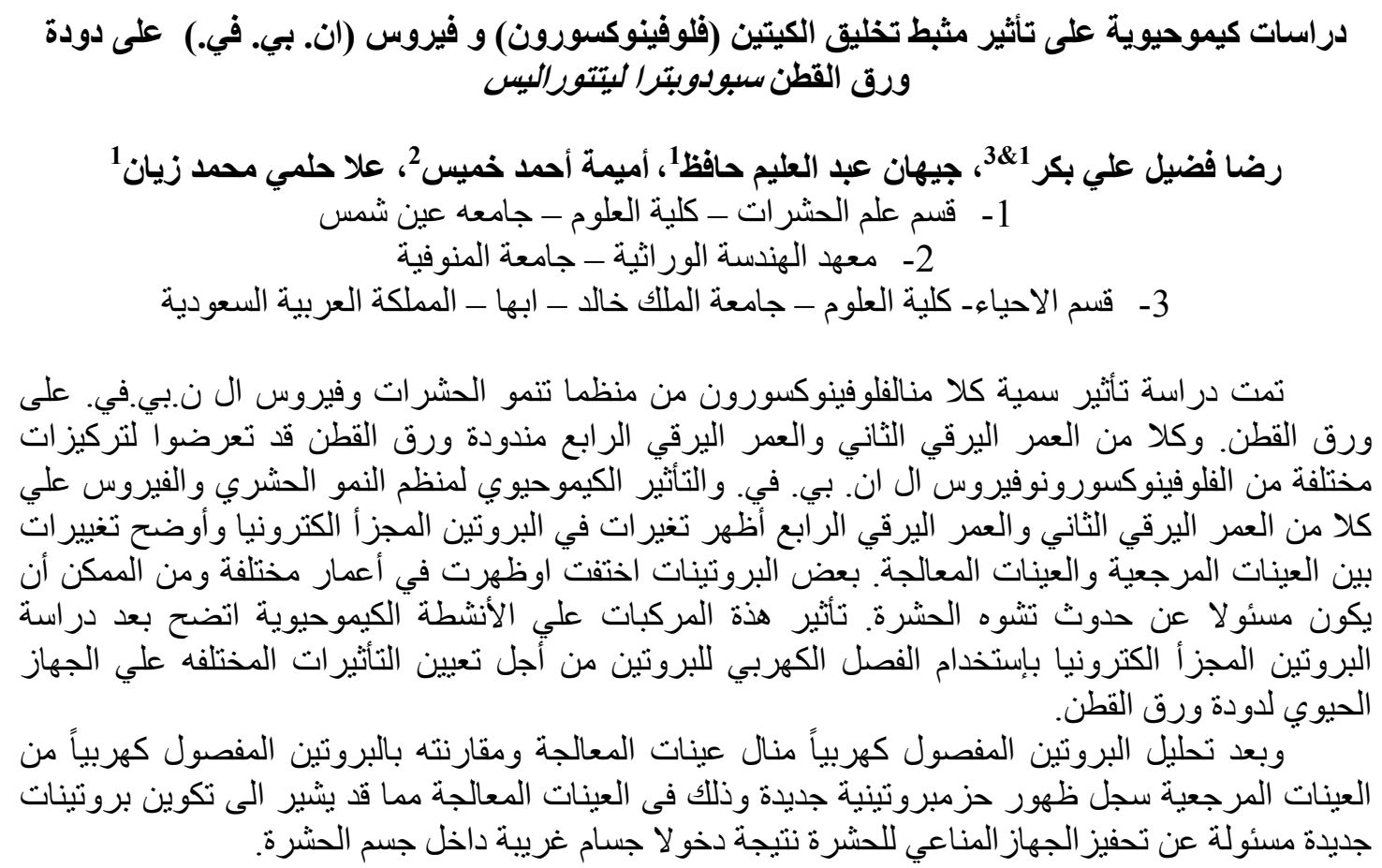

